\title{
AN UNUSUAL OPPORTUNITY TO INVESTIGATE THE PSYCHOLOGY OF LANGUAGE*
}

\author{
From Louisiana State University
}

C. H. BEAN

A new approach to the investigation of the psychology of language is supplied by this case, a child who was born blind and gained adequate sight, through operations, during the early stages of speech learning.

Lack of vision was due to congenital cataracts. Only enough light reached the retinae around the opaque cores of the lenses for his eyes to turn reflexively to its source. Before the pair of very successful operations at the age of 16 months, all the usual baby-like absorption in the colorful, moving, exciting complexity of the visual world was excluded. But this limitation produced in L's behavior a correspondingly larger amount of reaction to the great realm of sounds and their limitless combinations of qualities. This exaggerated interest in sounds as he heard and reproduced them was diminished for a brief period when sight first became possible, but soon resumed the dominant rôle, with the new interest, the world of light, as its able assistant. Every new thing that sight put into his hand was repeatedly drummed against another object or the floor and gleefully listened to, and its name was later added proudly to his vocabulary.

Subsequent manifestation of native talent in music, later rated very high by his music teachers, may have been an additional factor in his early progress in language. Seashore tests, given at 11 years of age, placed him in the highest percentile rank in pitch, melody, harmony, and memory, and in the next to the highest in rhythm. All these unusual factors combined to make stages in language learning much more pronounced and isolable for study than in other cases.

The evidence in this investigation consists of records made daily during his first four years, and frequent records thereafter to his twentieth year. Degrees of certainty were indicated in all the notes. Although attention was not given to language data alone, it was

* Accepted for publication by Carl Murchison of the Editorial Board, and received in the Editorial Office, October 29, 1930. 
limited to the observation of the types of behavior directly affected by the temporary absence of sight and by its subsequent presence. The thoroughness of observation that this restriction of the field made possible is in a measure evident in the abundance of the outline notes, which, in that brief form, would cover about nine hundred printed pages.

After his operations, when the charm and novelty of the visual world had worn off, his habit of attending to the other kinds of sensation than visual made $L$ satisfied with any visual impressions that were just sufficient to signify that the object present was of an old or of a new kind, or with no visual impression at all. Nevertheless, he insisted upon the pronunciation of its name. The effect of deficiency in sight, therefore, upon L's ability to express himself, as the details of this article will show, was not only temporary retardation of his manual skills, but also, in compensation for this lack, the acquisition of marked efficiency in auditory perception and vocal expression.

After his third month, L, like other children, found no other plaything so interesting or so capable of varied use as his own voice. Limited in most of the other forms of infant play, L imitated a countless number of the sounds that he heard. Many persons, even parents of children of L's age, expressed astonishment at the range and the individuality of his repertoire of mimicking noises and the close resemblance to their original sounds. He never said "bow-wow" or "moo" or "cock-a-doodle-doo," but made more exact facsimiles of the animal noises that these conventionalized forms aim to represent. If he had learned to creep and to walk before he could see, he could not have spared the time and energy from those employments to learn this long list of cries of birds and animals, roaring of storms, the racket of modern vehicles, and other city clatter.

Sound had such a large place in L's mental life, and the notes were sufficiently complete that it may well be expected that his case will throw a strong light upon the psychology of language and therefore upon the teaching of language arts. Theories of language agree that an individual's speech has its beginnings in the vocalizations of infancy, but these sources have not been sufficiently analyzed. Preyer advocated the doctrine that words are the lineal descendants of primordial babblings. Sully believes that speech has its origin more largely in the happy, cooing, song-like sounds of babyhood. According to the interjection theory, the cries that manifest emotions in animals, 
in primitive man, and in infants become associated with the ideas that are kindred to these emotions. Kirkpatrick says,

"At first the child has no cry except for pain, and little or no variation in its cry to express different kinds of pain. Soon, however, the cry of anger or the wail of disappointment is differentiated from the cry of physical pain. At about the same time or a little later, other cries, screams, gurglings and cooings suggestive of energy or of pleasurable contentment are made" (3, pp. 248 ff.).

My notes contain evidence that each of these views is but a partial truth. No less than 19 of L's sounds and combinations of sounds were linked each with its large group of closely resembling situations from the time of their first appearance. Even more significant is the fact that several of these connections were clearly evident within a few hours and even a few minutes after birth, too early for any one of them to have been the result of experience. For example, there was one cry, a combination of short $u$ and short $a$, "uaa, uaa, uaaaa," that accompanied hunger, fatigue, and all other uncomfortable situations and another cry, a union of short $a$ and long $e$, "aeeee," coincident with unquestionable causes of pain. When he was 3 months and 2 weeks old $m$ was pronounced with perfect distinctness, followed by $u h$, in a new cry, "mmuh, mmmmmmuh," uttered when persistent appeals brought no food. In his case, as in that of two other infants that I studied, this combination of sounds, this innate accompaniment of dissatisfaction, disappointment, and distress developed gradually through the consequence that often followed this cry into associations with mother, that faithful reliever of every discomfort, satisfier of all dissatisfactions. The cry, "uaa uaa uaaa," mentioned above, was the earliest that was observed to become modified into two cries (third day). He was so weary that day that the cry sounded like ' $w$ w waa," and was followed by provisions made for rest. This cry thus became differentiated gradually from the other cry, which was followed usually by the supplying of food. At 2 months 1 week 4 days, while happily amusing himself with a singsong, approaching hunger drifted him into the hunger cry. Thereafter a sing-song hunger cry replaced the usual cry of hunger. This left the other baby annoyances with "uaa uaa uaaaa" as their unaltered call. Many sounds originated in like manner from the 19 primary ones.

At first all sounds, except perhaps some grunts and clicks, even 
those of crying and of fretting, were vowels, because the only organs used were the vocal cords and the open mouth cavity. With the exception of the semi-obstructed cry of fatigue mentioned above, no definite consonant appeared until the last week of the third month, when he was heard in an unmistakable "ha ha" of laughter. The remaining consonants followed each other in slow succession. $T$ was sounded for the first time at 6 months 3 weeks, $p$ and $k$ at 7 months, $d$ at 7 months 2 weeks, and $n$ at 10 months. These observations were verified by the fact that, when a consonant put in its appearance, it reappeared almost hourly.

The record of L's earliest grunts and clicks is not very abundant; but limited early data and more abundant data recorded later indicate that many of the sounds were made while he was fretting and few while he was joyously happy. By the middle of the fifth month he had an astonishingly large vocabulary of clicks, gurgles, and grunts. A note was made at 6 months 3 weeks of his grunting, gurgling, giggling, and displaying other vocal and motor signs of happiness while an electric light was repeatedly turned off and on, and a few days later he grunted and occasionally clicked whenever he wished this process to be repeated. At 5 months 2 weeks, if his father failed to play with him as soon as he came home from work, $\mathrm{L}$ made fretting, sputtering, and grunting sounds. At 6 months 1 week he had the habit of sniffling and rattling his bed, sounds that had awakened his parents and brought them to him. This last case and many others in which grunts and clicks and other sounds were associated with specific results that they brought about may serve as an illustration of the manner in which the simplest natural sounds and movements become means of expression. As early as 4 months 2 weeks, when his efforts to regain possession of an object that had slipped from his grasp made him grunt, and the object was promptly replaced in his hand, the reaching and grunting, louder and louder grunting, was repeated after the object had been allowed to slip again and again. Likewise, when fretting, apparently weary of being in his cab (5 months 1 week), he raised his body as high as he could with his heels and elbows resting on the cab and accompanied this effort with a guttural squeal, probably the only vocal utterance that was possible while in that position. The relief that was promptly supplied fixed this sound as the habitual symptom of uncomfortableness of posture, and later it became the symptom of ennui with any experience. In this manner each grunt and click that was retained temporarily or 
permanently became at first the symptom, rather than the expression, of the presence of the need for which this symptom usually brought satisfaction. Through similar processes, accidental and natural movements of the face became mere manifestations, and subsequently became expressions of his feelings and emotions.

Young children smile rather early, as did Major's (4) at 3 months 2 weeks. L's smiles were at first homely smirkings, but were always immediate accompaniments of satisfaction after a high degree of physical discomfort. His first smile of this sort was seen on the second day of his third week; and smiles became increasingly frequent, more easily induced, and more attractive. He could not imitate smiles because he could not see. At 2 months 1 week, for example, he smiled broadly when his hand was patted, and closed, then opened the hand each time for a repetition of the pleasing contact. An interesting sound brought the smile response at 2 months 2 weeks. Smiles were present on many, many sorts of happy occasions during the first two years. When two callers departed and his mother could be free to manifest an interest in him ( 5 months 1 week), when her songs began, or when she entered upon the last especially rhythmic line of each stanza ( 5 months 3 weeks), when electric lights were snapped on or off, or later when we imitated his sounds, the smiles were sure to come. However, during the last two weeks of his third month and first two weeks of his fourth month, owing to illness and subsequent low vitality, smiles were entirely absent. But he no sooner recovered his usual vigor than the smiles returned. But when $\mathrm{L}$ first became able to see, he was too busy connecting the now visible world with his already complex, familiar world of auditory, motor, and contact senses to pay enough attention to faces to learn to respond to smiles with smiles. It seemed that the non-human environment which was absorbing his attention provoked smiles too seldom to keep their instinctive inclination active, for his smiles and laughter almost ceased. By all manner of efforts that could be devised, his parents multiplied his pleasant experiences, especially with people, and permanently revived the smiling, laughing, joyous part of his nature.

Even though little children, like young animals, instinctively seek bodily contact with their kind, in children kissing is undoubtedly a pure acquisition. The pleasures derived from contact, however, made $L$, like other children, desire to be embraced and less and less unwilling to endure being kissed. Finally, with the addition of playfulness in the process, he developed these movements into manifestations of joyous affection by the time he was 3 years old. 
There is not much evidence to show how shaking of the head in negation, or how nodding in affirmation, are learned. When $\mathrm{L}$ was 7 months old he began to move his head from side to side in refusing food offered him. Occasionally, in order to emphasize his refusal, he uttered a grunting sound with each movement of the head. This sound developed early into "huh-uh." We had carefully avoided all opportunity for him to learn this negative sound by imitation. It is said that some children seem to have learned to nod by reaching for food with the mouth. This was less possible for $\mathrm{L}$, because he never looked for the approach of the bottle or the spoon, and opened his mouth only after it has been touched, a habit learned before sight was made possible. This belated his affirmative nod until his nineteenth month when he was taught it by a friend.

In the same manner that the pulling at the clothing of an adult in the desire to be lifted up becomes reaching, and becomes beckoning and gesturing in most children when the adult is somewhat farther away, so the opposite gestures and the clicks and grunts that accompany disgust grew in $\mathrm{L}$ much more evidently out of the act of pushing things away than out of the facial attitudes accompanying the ejection of disgusting substances from the mouth.

L's reliefs, satisfactions, and joys did not begin to be accompanied by sounds until he was 2 months 1 week 6 days old. He then uttered the long oo and short $u$ vowels, "oo u," frequently when his wants had just been satisfied. His first laughter, an unmistakable "ha ha," referred to above as the first sound containing a consonant, occurred at 2 months 3 weeks when his mother was singing while bathing him. Laughter increased in frequency from that date to 3 months 3 weeks when it was modified by the greater heartiness with which he laughed into "ha ha ha uh" (inhaling on $u h$ ).

There was a clear-cut manner in this child's transitions from the single type of shriek, that is, the baby's spontaneous vocalization with all manner of pains, from the one wail that originally accompanies discomfort of every conceivable origin, from the smile and the ha-ha that are the indubitable symptoms that all is well, to the several pain screams, to the differentiated wails that serve the parents as clues to the specific causes of discomfort, and also to the varied smiles and grins, the ha-ha's, he-he's, ho-ho's, giggles, and squeals of delight that are evidences of multiplying forms of mirthful emotions. Careful observation of several other children, in the light of these evidences from one child, justified the belief that, although temporary blindness 
had made the steps in his vocal language more pronounced than theirs, nevertheless, his progress was like theirs in every other respect. This breaking-up of single forms of behavior into many, and the fixing of each as a symptom of a need that requires and gains the proper kind of response from parents is doubtless the method by which all normal childhood differentiates simultaneously its mental life and the fundamental sounds and gestures of its language.

Thus, as experiences multiplied, special vocal responses to these experiences became more frequent. Because $\mathrm{L}$ was limited largely to a world of sound during his earliest months, he paid more attention to sounds than other children with their multitudes of visual interests. Whenever the noisy city environment in which he lived failed to entertain him with novel experiences or sounds intrinsically pleasing, as music, or noises that were interesting because of their former relations to him, he occupied himself with haphazard vocalizations or playfully rehearsed one after another of his most recent vocal accomplishments. A nasal $u$ prolonged and then abbreviated (5 months 2 weeks), $p p$, purely asperate ( 6 months 2 weeks), "da-de-da-di-gago-di-da" ( 7 months 3 weeks) are types of sounds that he practiced.

The desire for social approval is the strongest inducement for a baby to repeat a sound until it becomes a part of his permanent repertoire. Children try to attract attention, even before the middle of the first year, by every means available, by their voices, by their smiles, and by facial and bodily antics. Later they practice skills of all sorts for no other purpose than that of making a social appeal. L had a few limitations in this connection because he could neither do many motor acts nor readily see the effects of his sounds or movements upon others. But after he found that he could attract attention by means of his voice, his vocalizations for that purpose were exceedingly varied and persistent. Through these efforts to get the approval of others he eventually found that nothing was so successful as the repetition of sounds that he heard, especially those of people who were making sounds at him. Although a record dated 2 months 3 weeks stated that he was not interested in the sounds that other people made, another note made at 3 months 2 weeks 5 days indicated a rapidly growing interest in those sounds. But his response to sounds began much later. When he was 6 months 3 weeks old, his father shouted from another room in reply to L's shouts. L shouted again and waited until he heard a response. Throughout a long, varied series of this shouting, no tendency was evident on his part to imi- 
tate the shouts that his father varied in length, quality, and pitch. At 7 months 3 weeks he made modulated grunts to attract the attention of a young woman he liked. At the age of 16 months, without suggestions from anyone, he repeated the entire repertoire of his sounds apparently in order to please his father whom he had not seen for three weeks. These are but a few samples of a continuous watching for opportunities to gain the attention of those about him. He made little effort before he was 11 months old to imitate words that were said to him, even in self-imposed language lessons, in which he begged for one object after another to be named. But as early as 7 months 3 weeks he obviously found that his mother was pleased when he said "a-boo" in response to her "peek-a-boo," for he continued it. At 9 months 2 weeks he kept his father's attention by apparent efforts imitatively to say "papa" by making an aspirate sound "p-p-p." He was equally happy at ten months in winning approval with "a-to" for "tick-tock." After he was 11 months old he often tried to imitate words, delighted meanwhile by the approving response, "That's the boy!" Later he became so imitative that his progress was astonishingly rapid. In the learning of sounds, in acquiring the ability to pronounce words, and in habituating himself to the structure of English sentences, L's primary motive, without doubt, was the gaining of social approval. Imitation was a means to that end, not an end in itself. L would not have imitated sounds or anything else at this stage if he had not gained any reward other than successful reproduction of what he heard, because, although he usually began it without inducement, he stopped the moment the social response ceased to come.

Long before $\mathrm{L}$ could pronounce a word, he knew the meanings of a great many words. Owing to the fact that children and animals learn isolated words more readily than words that are welded together into sentences, and also because children use words singly at first, we accustomed ourselves to conversation with $\mathrm{L}$ in single words or very short phrases. He soon discovered that we were pleased when he made an appropriate reaction to each word that we said to him. We predetermined the response by saying the appropriate word for a movement that he happened to be performing, or for the object that he was examining. Thus he formed association links between 152 words and phrases and the objects or acts to which they belonged, before his operations when he was a year and six months old. Some words were symbols for complex groups of relations; some had but 
a single relation; many of them merely recalled the objects of which they were the names. No record was made unless three or more repeated reactions proved that the associations were permanent.

$L$ 's reactions to the first words in this list depended to a very noticeable extent, while he was learning them, upon the tone in which they were spoken. Low harsh tones caused him to stop whatever he was doing and look alarmed. Gentler, higher tones that succeeded each other in a melodious order made him smile, laugh, and be active. These apparently acquired reactions to a large list of words that usually were spoken with an appropriate tone impressed their meanings much more quickly than others: e.g., "no, no," "peek-a-boo," "big boy."

By watching the face of an adult, the child not only learns at this age how to use the vocal organs in speech, but also acquires the emotional attitudes and is aided thereby in grasping the meaning. Owing to his inability to see faces during the first 16 months, and his resultant inability to interpret facial expression, he gained little or no help from visual observation of peoples' mouths while talking. As a consequence, his keen mind for sound did not save him from making such errors as "meap" (meat), "grate nuts" (grape nuts), "stean" (steam), "betweem" (between), and even "blessum" (blessing). But as no baby-talk, except a very few such words as "choo-choo cars" and "kitty," was heard, L learned to pronounce nearly all words correctly when he first used them. Moreover, he never used $k$ for $t$ or. $t$ for $k$, nor did he employ substitutes for $l$ or $t$, all of which errors are common among children whose attention has not been keenly and habitually fixed upon sound. This shows that children's mispronunciations are due to crude perception, not to inability to pronounce the elementary sounds.

In L's first attempts at pronunciation he put no more than two letters, a consonant and a vowel, into a syllable, and sometimes failed in doing even this. For example, at 14 months 3 weeks " $\mathrm{j}$-j" was his first attempt at riggi-jig-jig. When he was 11 months old, he pronounced correctly, th, both subvocally and aspirately; but, because he did not succeed after much self-imposed practice in pronouncing $t h$, especially in combination with other sounds in words, he made no further use of it until he was four years old. He often inadvertently pronounced German umlauts, gutturals, and both German and French trills.

Like other children, $\mathrm{L}$ at first used single words to express each 
unit of experience. Chamberlain (1) calls words thus used "rhemes." The rheme is usually treated as equivalent to a complete sentence: but these incomplete units of expression are employed, not because children have few words and little knowledge of the idioms and sentence structure of their native language, but more largely, I am convinced, because their thoughts are correspondingly incomplete. The baby that says "milk," does not mean, "I want a bottle of nice, warm, sweet milk"; for it has never known any other kinds. Therefore, the one word stands for an undifferentiated idea, not an interrelated thought. Besides, "milk" has been the only word necessary to bring this food. As in the case of seven-year-old Helen Keller, no distinction having been made between the milk, its qualities, its container, and the bringing of it, the ideas "warm, sweet, white, liquid," and even of "bring" could not have been implied in the word "milk." Incompleteness, I find, is the most obvious feature of infant reaction. I should define a rheme as the expression of a baby's undiscriminated, unqualified, incomplete idea, not of a thought in the adult sense.

Sometimes the most meaningful word would have been a noun in a sentence of an adult, but was more like a verb in the rheme. "Lap" meant to L clearly the act of being put on the lap rather than the lap itself. Likewise, the preposition "over" and the adverb "now" often had verbal significance, and the verb "knock" seemed to have definite reference to the some one, not to the knocking. Therefore, as Lukens and Chamberlain have said, attempts to classify these rhemes as to their parts of speech are useless, except as it indicates the following facts: It is the word or words most pregnant with meaning that are favored by vocal stress in adult language and that are therefore seized by the baby as the conveyer of its fragment of thought.

The use by $\mathrm{L}$ of more than one word in a single expression was found to mean that the rheme idea was giving birth to other ideas through manifold varying experience. Sometimes the several words constituted a phrase. More often they did not. One day (2 years 2 months), when a man began working noisily on the floor above, $\mathrm{L}$ exclaimed, "Papa-no, Jasper." A few days later he said, "Letter, papa," meaning a letter from papa, insofar as he was able to have that thought. "Up" became "stay up." $\mathrm{He}$ used rhemes in commands, entreaties, and other emphatic matters, in imitation of adults, no doubt, long after he had found them inadequate to express his richer thoughts. 
Rhemes that stood for ideas derived from tactual, auditory, gustatory, and motor senses and the few visual ones that related only to light and color, which was all that he could sense before the operations, constituted nearly $90 \%$ of his early vocabulary. When his sight led him to explore also the realm of vision and to be more active, words that refer to visual objects were rapidly added and, in proportion to their increase, the rate of accretion of the other types of words decreased. There was also rapid enlargement in the tactual-motor, the auditory-motor, and the visual-motor vocabularies because of this greater amount of movement. It is evident that, although varied experience adds to the vocabulary proportionately to the widening and deepening in experience, the addition of a valuable sense temporarily reduces the contributions of the other senses, but subsequently combines their results with those of the new sense and thus multiplies concepts and their word symbols.

L sought new ideas for new words and new words for new ideas with great zeal, and if they were not supplied, he invented words for ideas that he wished to express, and ideas for words that he heard. Late in the fifth year he called a sunbonnet an "apron hat," a towel he spoke of as a "wipe-it-dry," and a convict's uniform a "zebra suit." On seeing an elevated railway train for the first time, he shouted, "See street cars upstairs." Also he interpreted and misinterpreted many words. He was always disappointed when he was unable to learn the name of a person, place, or thing that appealed to his interest. He appeared to feel that if he knew the name, he was master of the thing named. This seems to be characteristic, not only of children and savages, but of all men. Few adults have rid themselves entirely of the tendency to be mystified by words, especially by words that are hard to understand, and they are inclined to judge any unusually clear discourse on a subject that is known to be deep as lacking in penetration.

A word was not recorded as part of L's vocabulary until he had used it properly several times. It was not considered necessary to omit from the list any word because his knowledge of its meaning was incomplete. Proper nouns are more difficult to learn than common nouns, but are available as means of expression, and are therefore included. As the words am, was, been, and good, better, and best are distinct lingual achievements, these and similar words were recorded as separate. Many children do not know that such words or even their ideas are closely connected until they study formal grammar. 
The recorded number of words in L's vocabulary at three years was 1149 , and at three and a half years the number of words was 1896. In the 46 vocabularies found by Waddle (5), the average size of the eight vocabularies of children three years old is 1407, with a range from 631 to 2282 . Therefore, I am convinced that Waddle's are a somewhat select group of vocabularies from children of educated families, families in which attention was given to vocabulary building. We made an effort not to boost his language, but to supply only the words that he sought. Chamberlain (1) is no doubt approaching the norm for children generally when he gives the average of children three years old as 642, for Whipple's (6) child, who lived with two educated parents and was encouraged in every way to acquire words and their meanings, is a good example of the select group and had a vocabulary of 1177 words at three years. Humphrey's (2, p. 6) child acquired 1127 under like conditions. Vocabulary studies give indubitable evidence that there are marked individual differences in the number of words. These dissimilarities are due probably to unlikenesses in richness of experience, to consequent number of interests, to opportunities to associate with educated adults in such a way as to widen the experience and the vocabulary and with children with whom to deepen word impressions, and whether the adult companions are educated enough to have abundant words and are inclined to encourage and assist in the making of ideas as well as the association of them with their symbols. The accumulation of words is clearly a cause and an effect of a corresponding growth in ideas, and in their interrelations.

Children, like primitive peoples, have at first not more than one pronoun and no distinctions of number, of gender, or of person. In fact, children are at first not inclined to use pronouns until they have become accustomed to nouns in sentences. $\mathrm{L}$ used pronouns without specific number, gender, or person when he was 22 months old. A little later he discovered the difference between you and I, but soon forgot it, evidently because his thinking and use of language were too immature as yet for the advantageous employment of the personal factor. He practiced plural and singular use of nouns at 2 years $3 \mathrm{I} / 2$ months. Singular and plural number in pronouns were acquired immediately afterwards without difficulty. Here is another case of the concept and the form appearing simultaneously. As we refrained from assisting him until interest in person and gender reappeared, he called himself "he" and "you" in imitation of our conversation about 
him and to him, but occasionally spoke of himself as "I," "me," and "she." He sometimes used pronouns at this stage with reference to other people; but, like other children, he usually employed nouns. He began by referring to his father as "papa," "he," "she," or "you." Briton says that most children use $m e$ in referring to themselves. Insofar as this is true it is probably due to the fact that, although $I$ is used by adults more frequently than $m e, m e$ is more often pronounced with emphasis. $L$ was often heard trying to puzzle out these relations. When he was nearly three years of age, he used $I$ constantly in talking about himself to an adult friend; but after his departure, he said, "You mustn't say 'she' for a man and 'she' for a woman." One day he evidently believed he had solved the gender problem with regard to Chicago, for he excitedly exclaimed, "It's not 'Hecago,' it's 'Shecago!'” During this period of interest in gender, person, and number, without anyone's suggestion, he said hesitatingly, "I jumped, you jumped, she jumped, me jumped, they jumped, her jumped." He had never heard anyone conjugate, decline, or do anything in formal grammar before this utterance; but, as he seemed to be ready for it, assistance was given then in straightening out these difficulties. His readiness was evident in his seizing of every opportunity to put into practice everything that he was taught and in the self-imposed drill in which we often heard him giving such sentences as, "He said that I might have his French harp, if I don't bite it with my teeth." One day, just after the fundamentals of gender, number and person were in proper daily use ( 3 years), he was watching the preparation of a familiar rooster for roasting, and, as the oven door was finally closed, he exclaimed, "When he's cooked, he won't be he: he'll be it." This, as I see it, is evidence that the drill was timely, for he was linking it with experience.

Owing to L's interest in color, because it was often visible before he could see objects, adjectives that designated the colors of objects became part of his vocabulary during the ninth month of the second year, whereas other types of adjectives were noticeably few until much later. These facts coincide with other data that indicate that (despite adult obtrusion of qualities into the experience of children) they are so busy acquainting themselves with objects and their uses that the qualities of objects play a less important part in their mental life, and therefore in their language, until there is a large enough fund of nouns, and until the nouns are familiar enough to lend definiteness of meaning to their modifiers. Comparison of adjectives became possible almost as readily as use of adjectives, strange to say. 
Adverbs were added much more slowly than adjectives. Verbs were multitudinous and familiar before adverbs were used. "Here" and "there" were distinguished by the middle of the twenty-fourth month. At $2 \frac{1}{2}$ years "yesterday" meant past time in general, and "this afternoon" referred in the same indefinite way to future time. Later "tomorrow" signified some time after today. It is possible that our English idioms, "the day before yesterday" and "the day after tomorrow," being too complex for the child to grasp early, confuse all references both to past time and to future time. At $4 \frac{1}{2}$ years, when his ideas of space had outgrown his vocabulary temporarily, he met his needs with such inventions as "farer" (farther) and "beyonder" (farther yet).

Strange to say, $\mathrm{L}$ used almost no natural or conventional interjections. He expressed his emotions, which underwent rapid development between the ages of 16 months and $41 / 2$ years, by modifying the quality of his voice, or by two or three such expressions as "goodygoody," and by movements of excitement. This was because even the less objectionable interjections were never heard by him, not because he was unemotional.

Studies of childhood indicate that collective ideas, generalizations, and concepts develop more slowly in children's minds than one would infer from casual observation. Children are often observed reacting in a similar manner to objects of the same class or to circumstances that are only similar as though they have class ideas. There were evidences in this case that early reactions of this sort and many of the later ones resulted from failure to discern differences rather than from the ability to discover similarities and form them into concepts. It seems difficult for a child to learn when an idea that fits one case will fit another that has some factors that are like and some that are unlike the first case. At the middle of the sixth month, for example, $\mathrm{L}$ learned to refrain from playing with his bottle in an objectionable manner whenever he heard "no-no." Later when he heard "no-no" while he was irritating his eye with his finger, he looked puzzled, then laughed, but did not discontinue the undesirable act until his mother drew his finger away. Thereafter he inhibited either of these two acts whenever he heard "no-no"; but it was necessary for him to learn several more inhibitions, one by one, before he succeeded in making this into the idea of quitting whatever he was doing when he heard "no-no." He perfected his generalizations of some things about the middle of the fourth year by monologues of 
the following kind: "Jelly isn't black: it's dark red." "The piggy went to market at six o'clock, not seven o'clock." "Is it about noon or pretty near noon?" "Did you say perhaps we would go, or maybe we would go?" "If you think so, it is better than if you suppose so." No doubt the conscious, analytic manner in which $L$ realized many of these distinctions is due to the unusual interest he had in the world of sound and language; but observation convinces me that all children learn language in a similar but less obvious manner.

Soon after $\mathrm{L}$ was 2 years old he became more interested in combining his own words than in the acquisition of new words. As a natural consequence, the structure of his sentences appeared more and more that of sentences. "Go home get toast," and "Looking down on street," are expressions selected from those used when he was 2 years 2 months old. After he had become able to use complete sentences, however, he seemed to find it necessary to use them in order to be explicit while talking to another child, but continued to talk to adults in less complete sentences. Interest in new words alternated with interest in sentence structure at varying intervals. Sentence building was especially dominant in the early part of the fifth year. The word periods seemed to coincide with the widening of experience through travel and other eventful additions of ideas, and the sentence periods were the uneventful interims in which former happenings were remembered and were reconstructed by imagination. If it is true that children improve faster in language through their association with children, as is supposed, than through contact only with adults, one of its causes is the necessity for the more adequate expression of their thoughts that are intended to be understood by children. But surely the fastest progress can be made with the presence of both children and adults, because adults supply the new words and the sentence models and idioms, while children are stronger stimuli for conversation about things interesting chiefly to children.

Before this period of sentence building, L's early questions had begun. They made their first appearance, of course, in the rheme stage. "Telephone wires?" was a question of this type (2 years 2 months). Later he often asked a question in the form of a declarative sentence in which one or two words were omitted to be supplied by the answer. By the third month of the third year his questions began to assume such proper forms as "What's that ?" During the fifth month of his third year he also answered a few questions properly. 
As soon as $\mathrm{L}$ could use sentences, an effort was made to teach him to carry on conversation. But this confused him. He repeated the questions asked him, word for word (2 years 3 months), and in response to "Good-bye, L," he said, "Good-bye, L," and later replied to a question with an answer in interrogative form. One day he described what he had seen down town ( 2 years 5 months) in the following manner: "Did you go down town on the street car? Did you see lots of people? Did you hear band music? Did you ride home with Mrs. M. in her automobile?" He often told stories partly in interrogative and partly in declarative form in imitation of the semi-conversational manner in which the story had been talked over with him. The recovery from this result of slavish imitation was brought about by catering to the imitative propensity by his having questions put to him and all the possible answers suggested in declarative form. He readily stated his answer then in a declarative sentence, and soon developed an interest in wording his own answers in declarative form, and later spent hours in monologues like the following: "Is salt-box broken all to pieces? No, it isn't broken all to pieces; it's broken only on top." Anyone who listens to the selfamusement talk of any child in its third and fourth years will hear this kind of imitative practice of the sentence forms that are being acquired, and will see in it the close adherence to copy that first misled and then usually led aright this little learner.

Successful teachers of foreign languages assert that the chief diffculty encountered in the teaching of foreign languages to adults is their insistence upon rational learning instead of imitative practice. Every effort of the teacher to explain perpetuates in his adolescent or adult student this ineffective language-learning habit. A minimum of discussion of the language being learned, as few rules as possible, and as much mechanical imitation of the correctly spoken language as time will permit and repetition of assignment produces the best results with adults as well as children until thinking in the new tongue about common things has become readily possible.

When $\mathrm{L}$ was $2 \mathrm{r} / 2$ years old he begged to hear his favorite stories and songs, not by titles that he knew, but by telling part of each story. For example, he said, "Sing about 'Rock-a-bye baby on the tree top, and when the wind blows the cradle will rock, and if the bough breaks the cradle will fall" "; or, "Tell about "There was a little baby. It didn't have any bed. It lay in the hay. The cows stood around and looked at the baby. The baby's name was Jesus. 
It was a long time ago on Christmas.' Tell that story." The greater originality of the wording of the second descriptive title was due to the fact that this story had not been given to him in the same words twice, whereas the words of the stories read to him and the songs were, of course, fixed.

$L$ did not always insist on the exact repetition of the original words of stories as most children do, because many stories were told in different words and in greater and greater detail as soon as $\mathrm{L}$ had grasped the most fundamental incidents. The purpose of this procedure was, of course, the avoidance of unoriginal, mechanical habits like those out of which he had previously been led and the development of the proper balance between imitativeness and originality. It was surely owing to this training that he became able to either repeat word for word or to relate with a considerable degree of originality. At 2 years 6 months he told part of the story of "Three Bears," with here and there an original touch: "Mama bear made some soup-bean soup. Had to wait to get cold. Papa bear said, 'Somebody has been sitting in my chair.' Papa bear said, 'Somebody has been tasting my soup.'" A month later he told it as follows: "Well you know there was a papa bear and a mamma bear and a wee, wee baby bear. And the mamma bear made some soup, and it was hot. So she said she thought they'd better take a walk down to the park, and wait for the soup to get cold. Then they put the baby bear in his cab and took him down to the park." When he was 3 years old, he told the entire story to his doll with intentional modifications that deviated farther and farther from the original form until the meaning was too different to be interesting. He then omitted that story for some time.

\section{SUMMARY}

The seeds from which a baby's language grows are more numerous than is usually believed. One of them is a cry, manifesting needs and discomforts. Another is an indication of pain. Several are the frettings, sputterings, and clicks, and the wails of impatience. There are grunts of exertion. There are vowels of gurgling and of sighs, when comfort replaces discomfort. Then the $h a-h a$, he-he, and $h o-h o$ of more and more hearty laughter, and the giggles and squeals of delight. Nineteen sounds give much evidence of being primordial.

At first, these are not, in any sense, expressions, but only natural manifestations of the conditions that accompany them. But adults 
supply the needs that these sounds reveal, until the need, its manifestation, and its satisfaction become conjoined, somehow, in the little one so that, when the satisfaction does not arise in its turn, fretting and sputtering come with other evidences of impatience. These sounds become calls for assistance, but it is impossible to tell exactly when this transition from manifestation to expression takes place, for it seems to dawn, rather than to flash into the young mind.

In the meantime these primordial utterances become modified, conditioned, and reconditioned. Two organic needs present themselves simultaneously, or a need arises while sounds are being made for their own sake, and its natural sound blends with the play sound that happened to be coincident with it. After an older person gives a baby the object that it is straining to get, the grunting that accompanies the baby's effort becomes the semblance of a request. Thus the many primary sounds become differentiated.

Variety of its own vocalizations is sufficient to interest a baby in its sounds, whether play with sounds is innate or not. Pure vowels are easiest to make and occupy the whole waking time at first. Then accidental closing or opening of the tongue or of the lips on a vowel adds a consonant, then another and another, to the vocal playthings. Vowels and consonants are thus in syllable-like unions.

The number of sounds that ultimately find a place in this selfimposed practice is astonishing. One cannot fail to hear all the vowels and consonants, diphthongs, aspirates, sub-vocals, nasals, German umlauts and tongue trills, French throaty trills and grunts, and even the Welsh $l$.

Then these syllables are rehearsed in grotesque mixtures. During the repetition of a syllable, or the utterance of one of these random series of syllables, someone discovers its resemblance to a word and the infant is rewarded by joyous fondling. This gives the kind of permanence that insures its recall under similar environmental circumstances. Although to the adult it is a word, to the child it doubtless lacks the most important essential of a word-meaning.

The mastery of syllables in every conceivable order puts the little learner in readiness to imitate. If no other imitation is innate, there is considerable probability of its being inborn to imitate sounds, for it was demonstrated in this case that it cannot be taught. Every possible effort was made to induce imitation of sounds that $L$ had mastered, of new, simple sounds, and of animal and of human sounds, but in vain. In several cases that I have observed in families and in 
orphanages, imitation began in both the tutored and the untutored immediately after syllables could be pronounced in every order. Then imitation monopolized L's day.

$\mathrm{L}$ was interested in another's conversation at $3 \mathrm{~T} / 2$ months, shouted in response to shouts, with no imitation even of changes in pitch or loudness at 7 months, and he imitated profusely at 11 months.

Words were used by $\mathrm{L}$ neither as words nor as sentences, but as fragments of language that symbolized fragmentary thoughts. Usually they were the part of a sentence that adults emphasized. The differentiation of elements in an idea, or the relating of an idea to another was followed promptly by an attempt at its expression. For this reason, any enrichment of experience, such as a journey, always greatly increased his vocabulary. On the other hand, whenever L acquired a new word, he begged for its meaning. His development in language and in ideas not only accompanied each other, but thus kept step with and stimulated each other.

It is futile to try to determine when each grammatical class of words begin to accumulate, because a rheme gradually, after several stages, ceases to be a rheme and becomes a word.

The sentence was most interesting to $\mathrm{L}$ and was improved most in the early part of the fifth year.

He continued to talk to home folks in rhemes for some time after he used sentences in talking to children and new adult acquaintances. Whenever the satisfaction of his desires depended upon clear statements, his conversation was more correct than at other times.

Contacts with adults added to his vocabulary and to his sentence forms and ideas and thoughts, and association with children increased the rate and efficiency of his self-expression.

Whenever the environment supplied few new ideas, L utilized the time in the practicing of recent acquisitions, but he made less progress than he did when necessity put it into use.

$\mathrm{L}$ asked questions in rheme form before he could use sentences; nevertheless, the questions asked by others confused him for a long time. He practiced many times talking to himself in a queer mixture of declarative sentences and interrogative sentences without answers. Then he repeated the questions of others, word for word, with evident effort to answer in the affirmative. Finally, he mastered question and answer conversation as though its secret had suddenly revealed itself to him.

Qualities of objects are uninteresting to little children until their 
time is no longer consumed in discovering the names of the objects in their environment, and what these objects do. Adjectives and adverbs multiply almost simultaneously, adjectives faster than adverbs.

Tomorrow and yesterday persisted for a long time in referring to indefinite future and past time.

Number in L's pronouns was evident as early as it appeared in his nouns.

Comparison of adjectives was present by the time some of the rhemes had assumed genuine adjective character.

Confusion of similar things is often mistaken for generalization, which develops very late.

It is evident that all children learn language by an identical procedure. They master, in succession, vowels alone, consonants in syllables, series of syllables, rhemes, words, phrases, declarative sentences, and interrogative sentences.

Early words refer to objects, later ones to actions, and then appear words assigning qualities to things and modes to acts. The forms of nouns and pronouns, of verbs, of adjectives, and of adverbs are acquired with them with their uses without any help from rules.

The fastest progress is made in the learning of language through its use; but throughout this was distributed a considerable amount of self-imposed practice.

A few decades ago, when Latin was the only language of classroom and campus, and today in some schools, students have been persuaded to ignore the fact that they are "high-browed" adults and have learned a new tongue exactly as do little children. They have applied grammar once in a while only as a test of correctness, have omitted translation, and have mastered the language largely through its practical use in the study of other lessons and in supplying their daily needs. Thus they have formed the desirable habit of keeping attention, not on the tool, but upon its work, and have gained much better and quicker results.

\section{REFERENCES}

1. Chamberlain, A. F. The child: a study in the evolution of man. London: Scott; New York: Scribner's, 1900. Pp. xii 498.

2. Humphreys, W. A contribution to infantile linguistics. Trans. Amer. Philol. Asso., 1880, 9, 5-17.

3. Judd, C. H. Psychology: general introduction. New York: Scribner's, 1907. Pp. xii+389.

4. Major, D. R. First steps in mental growth; a series of studies in the psychology of infancy. New York: Macmillan, 1906. Pp. xiv +360. 
5. WaddLe, C. W. An introduction to child psychology. Boston: Houghton Mifflin, 1913. Pp. xvii+317.

6. Whipple, G. M., \& Whipple, Mrs. G. M. The vocabulary of a threeyear-old boy with some interpretive comments. Ped. Sem., 1909, 16, 1-22.

Louisiana State University

Baton Rouge, Louisiana

\section{UNE OCCASION EXTRAORDINAIRE POUR L'INVESTIGATION DE LA PSYCHOLOGIE DU LANGAGE}

(Résumé)

C'est une étude d'un enfant dont les premières étapes dans l'acquisition du langage ont été très évidentes à cause d'un grand talent musical, à cause de cécité congénitale, et à cause de l'acquisition d'une vision presque normale, dans la dernière partie de la petite enfance. Ce cas nous donne beaucoup d'évidence que 19 sons sont innés. La dépendance des personnes plus âgées s'est montrée le premier facteur, l'imitation le deuxième, et l'exercice imposé par soi-même le troisième facteur du conditionnement de ces manifestations naturelles de nécessités physiques en expressions verbales de besoins physiques, mentaux et sociaux. Avant que la configuration primordiale, obscure, emmêlée, de n'importe quelle chose ne soit devenue changée en formes plus claires, son expression en a été loin d'être une phrase ou même un mot. Jusqu'à ce qu'il ait découvert par expérience que quelques types d'objects et quelques types d'actions ont été surtout satisfaisants, il n'a exprimé des distinctions adverbiales ni celles de l'adjectif, ni n'a modifié les formes des mots pour la personne, le nombre, et le temps, ni n'a changé l'ordre des mots d'une phrase pour faire une question. Donc un petit enfant apprend une langue plus normalement qu'un adulte, en la faisant servir ses buts, avec son attention non sur l'outil mais sur la tâche.

BEAN 


\title{
EINE AUSSERGEWÖHNLICHE GELEGENHEIT, DIE PSYCHOLOGIE DER SPRACHE ZU UNTERSUCHEN
}

\author{
(Referat)
}

Der Verfasser untersuchte ein Kind bei dem die anfängliche Sprachversuche wegen aussergewöhnlicher musikalischer Begabung, angeborener Blindheit, und des Gewinns, in der späten Kleinkindheit, von fast normaler Sehkraft, besonders deutlich waren. Dieser Fall bietet beträchtlichen Beweis dafür, dass neunzehn Laute angeboren sind. Die Abhängigkeit von Erwachsenen erwies sich als der erste, die Nachahmung als der zweite, und selbst-auferlegte Übung als der dritte Bestandteil bei der Umbildung von natürlichen Offenbarungen körperlicher Bedürfnisse in wörtliche Äusserungen körperlicher, geistiger, und sozialer Ansprüche. Ehe sich bei ihm die primitive, flüchtige, verwirrte Gestaltung irgend eines Gegenstandes in mehr bestimmte Gestalten aufbrach war seine Äusserung darüber weit davon entfernt, ein Satz oder auch nur ein Wort zu sein. Nur als er durch Erfahrungen entdeckte, dass gewisse Sorten von Gegenständen und gewisse Benehmensweisen besonders befriedigend waren, äusserte er abverbialeoder Eigenschafts-Unterschiede und modifizierte er die Form der Wörter nach Person, Zahl, und Zeitform und die Anordnung eines Satzes um eine Frage zu stellen. Ein kleines Kind lernt also eine Sprache auf mehr normale Weise als es der Erwachsene tut, indem das Kind die Sprache seinen Zielen dienen lässt und die Aufmerksamkeit nicht auf das Werkzeug sondern auf die Aufgabe richtet.

BEAN 